\title{
The Publishing of Matthias Held's Physiologiae clavis (1653) in Kèdainiai, Grand Duchy of Lithuania
}

\author{
Alina Šveistytè \\ Violeta Apšegaitė \\ Nature Research Centre \\ Akademijos str. 2, \\ Vilnius-21, LT-08412, Lithuania \\ E-mail:apviola@ekoi.It
}

Matthias Held's work Physiologiae clavis ('Key to physiology') was printed in Kedainiai in the middle of the $17^{\text {th }}$ century. Historically, it is noteworthy that the book came into being against the background of a clash between mainstream Catholics and Polish-Lithuanian Protestant (Calvinist) minority. The work is a very remarkable event in two aspects: as Lithuanian cultural heritage and as the first book of physiology published in the Grand Duchy of Lithuania (GDL). It is also noteworthy that the book is scientific but not a religious one. The title page indicates that it was printed in Kedainiai at the Gymnasium Illustre printing house, founded by Joachim Georg Rhet. Let us study the reasons why Held's book of physiological nature was published in this town. In that period seven printing houses operated in the GDL. Of these seven, the printing house of Vilnius Jesuit Academy boasted the greatest workload (Narbutiene, 2004; Narbutiene $\&$ Narbutas, 1998). In the $17^{\text {th }}$ century, the total of 865 books were published in Latin and 818 books were issued in Polish in the GDL (Ivanovič, 1998, p. 7; Narbutiene, 2004, p. 61). There was more than one reason why Held's book was published namely in Kedainiai. Primarily, owing to the general cultural environment created by the Biržai-Dubingiai branch of the Radziwiłł family, Janusz Radziwiłł (or Jonušas Radvila in the Lithuanian tradition) in particular. The Radziwiłł family made every endeavour to make Biržai and Kèdainiai the cultural centres of their possessions. When the Biržai and Dubingiai branch of the Radziwiłł family took hold of Kedainiai, the town gradually became the centre of Evangelical Reformed Church of Samogitia (Lukšaite, 2001, p. 11). After the death of Krzysztof Radziwiłł II in 1640, his son Janusz Radziwiłł became the Governor of Kèdainiai. 
Janusz Radziwiłł was a famous Lithuanian nobleman and magnate. Throughout his life he occupied a number of posts in the state administration, including those of Court Chamberlain of Lithuania (from 1633) and Field Hetman of Lithuania (from 1654). He was also palatine of Vilnius. Janusz Radziwiłł was a protector of the Protestant religion in Lithuania and the patron of many Protestant schools and churches. He created the religious environment which enabled to invite a famous scholar from the Protestant part of Europe to Kedainiai.

The contribution of the Radziwiłł family to the establishment of educational institutions is also worth mentioning. In 1625, on the initiative of Duke Krzysztof Radziwiłł II, a Calvinist school was established in Kèdainiai for Lithuanian, Samogitia and Užneris regions. In 1647, Janusz Radziwiłł transformed the school into Gymnasium Illustre. It was a Latin-type humanitarian gymnasium with all subjects taught in the Latin language. In total, eight languages were taught. Outstanding professors from Western Europe were invited to teach in this gymnasium. At the time the subject of natural sciences was not on the curriculum and the gymnasium was short of textbooks (Vaitkevičiené, 2007). We presume that Held's work could have been used as a training aid for the gymnasium: the work was not large in volume, merely 45 pages. Moreover, being published in Kèdainiai, the centre of Reformation, it could not have been popular at Lithuanian Catholic colleges. Furthermore, this book may have been offered to Janusz Radziwiłł's personal library.

The printing house was founded at Gymnasium Illustre in 1651 by Joachim Georg Rhet, who arrived from Gdańsk. The initiator of this deed was Janusz Radziwiłł (Jarczykowa, 1995, p. 67). Under his auspices, the institution operated successfully until 1655 and published several works in Lithuanian, German and Polish languages, according to Daiva Narbutiené (2004, pp. 79-80). It is also reasonable to assume that they published literature for the Calvinist school and special documents of the Radziwiłł family. Furthermore, at least four publications in Latin are known to have been printed there. The printing house in Kèdainiai can surely boast two important events-namely, the printing of Matthias Held's work and a state agreement between the Grand Duchy of Lithuania and Sweden. According to Ingè Lukšaitè (2001, pp. 17-18), Janusz Radziwiłł intended the establishment of the printing house at Gymnasium Illustre specifically for publishing a Lithuanian book Knyga nobažnystès krikščioniškos ('Book of Christian devotion', 1653). This book was a collection of hymns and prayers of the Evangelical Reformed Church. Naturally, the printing house was also used for various general needs. 
Peliksas Šinkūnas (1928, pp. 28-29) also mentions the publication of four Lithuanian books (in Gothic script).

Matthias Held's work was written in Latin. Its full title is as follows: Physiologiae clavis, septem res naturales dictas, praestrim corporis humani, reserans, quales sunt, elementa, temperamenta, partis solidae, humores, spiritus, facultates, et actiones, eo fine adornata, ut in quibus sanitas nostria consistat, clarum fiat / authore Matthaeo Heldio, philos. et medic. doct. - Caioduni: Typis Jaochimi Georgii Rhettii, illustris gymnasii Cajodunensis typographi, 1653 (Narbutienè \& Narbutas, 1998).

The author of this work introduces himself as Matthaeus Heldius. In international library catalogues his surname is spelled 'Held(ius)' (CERL, n.d.; Worldcat, n.d.). Only one edition has been preserved to this day. The original print is available at the National Library in Warsaw. This book tackles the issues of organism functioning and other questions of physiology. In the $16^{\text {th }}-17^{\text {th }}$ centuries, this was the only tractate on physiology published in the GDL. According to our informal translation, Physiologiae clavis deals with seven natural phenomena, in particular human body, its features, body constitution, interrelations, solid particles, fluids, vital spirit, capabilities and actions on which human health is known to depend. Our translation is built on the conception of physiology of that period.

Matthias Held's work was published in the middle of the $17^{\text {th }}$ century. Following the stagnation of science in the Middle Ages, the development of science took a new course, including that of physiology, in particular after the publishing of works of outstanding anatomists of the $16^{\text {th }}$ century (Andreas Vesalius, Michael Servetus, Realdo Colombo et al.). The first half of the $17^{\text {th }}$ century was noteworthy for such very distinguished thinkers and physiologists as René Descartes (1596-1650) and William Harvey (1578-1657), and Matthias Held was a contemporary of these eminent figures.

Meanwhile, in Lithuania, the knowledge of physiology was still based on earlier authors (Aristotle, Hippocrates, and Galen). In that period there was no faculty of medicine at the Academy of Vilnius, therefore lectures on life, animal anatomy, physiology, the same as those of natural philosophy, were given at the Chair of Philosophy and Mathematics. However, at the end of the $16^{\text {th }}$ century and the beginning of the $17^{\text {th }}$ century, when Jesuits were forced to ardently fight with the spread of Reformation in Lithuania, some professors at Jesuit colleges enlightened their students on the creed of Renaissance scientists, besides scholastic approach (Plečkaitis, 1975). 
Information on the author of this book is very scarce. The reference in Key to Physiology is about him being a doctor of medicine and philosophy. According to Polish historian Henryk Wisner (2000), a biographer and archive researcher of Janusz Radziwiłł, Matthias Held was the duke’s personal physician. We can find the following quotation in the book of this author: "without doctor Helder, [...] the situation is very unsatisfactory-noted Janusz Radziwiłł at the camp near Gorval ${ }^{1}$ (September 1653)" (Wisner, 2000, p. 269). Wisner underlines that the same year, 1653, Held's book Physiologiae clavis was published in Kèdainiai. The Germanic lexicon of outstanding physicians, published in 1886, shed more light on the personality of Matthias Held: "Held (Heldius) Matthaeus H., a well-known doctor, lived in Hungary around the middle of the $17^{\text {th }}$ century and was a physician of Duke Sigismund Rákóczi. In 1645, he wrote 'De arthritide', Stetini" (Biographisches Lexikon..., 1886, p. 148). The lexicon says that Held was a physician of Duke Sigismund Rákószi (1622-1652). Supposedly, after his death, Held became the personal physician of Janusz Radziwiłł, whose former personal physician Adam Freitag died in 1650 (Stownik..., 1885, p. 222).

The full name of the work De arthritide, cited in the lexicon, is Dissertatio medica de arthritide and it was published in Stettin in 1645. The printing location suggests Held's connection with the town of Stettin, which at the time was Lutheran and a part of Sweden (Meyers Großes Konversations-Lexikon, 1909, pp. 9-10).

The fate of Matthias Held following the death of Janusz Radziwiłł in 1655 remains obscure. Held is not mentioned in the biographical sources of Polish physicians, although one can find information on Adam Freitag and Kedainiai (Stownik ..., 1885, p. 222). There is also no mention of him in relevant French and Russian lexicons. Lithuanian medical history books by Juozas Meškauskas (1987) and Audronė Kasperavičienė (2006) also do not supply any facts about Matthias Held.

Although the $17^{\text {th }}$ century, in general, could boast a large scope of publications in the GDL, the same could not be said about medical books. While in the $16^{\text {th }}$ century, ten Latin books were issued in the GDL, in the $17^{\text {th }}$ century merely two Latin medical publications were published: a book by Matthias Held and a tractate on infectious diseases by Johann Hassler (Narbutiené, 2004, p. 153).

1 The township was located on the bank of the Berezina, a few kilometres away from the place, where it flows into the Dnieper. The Gorval castle belonged to the Dnieper line of castles and fortresses of the GDL. Both the township and the castle suffered considerably during the wars in the $17^{\text {th }}$ century (Lokotko et al., 2013, pp. 249-250). 
Also, a publication in Polish about the advantages of using essential oils in medical treatment by Kasper Schwertner (Ivanovič, 1998, p. 93) should be mentioned.

Valuable private libraries of noblemen of the GDL contained many medical books published abroad. As patrons of culture and promoters of education, the Radziwiłl family, one of the wealthiest families in the GDL, were known to have accumulated large collections of books (Narbutiené, 2001). Janusz Radziwiłł had a personal library in Kèdainiai. According to Ingé Lukšaitè (2006, pp. 34-43), the library was meant for his personal needs rather than to represent the family. The library's book list contained 183 publications, including four from the medical sphere: three in Latin and a book in Flemish which dealt with curative water. Held's Physiologiae clavis is not in the list. According to Wisner (2000, p. 268), the library's inventory was compiled somewhere between 1645 and May 1653, therefore Held's publication could not have been included.

In conclusion, in 1653, Physiologiae clavis - the first book on physiology in Lithuania—written by doctor of medicine and philosophy Matthias Held, a famous European physician of that time, was published in Kèdainiai at Gymnasium Illustre printing house. The emergence of this book in Kedainiai was spurred by the cultural environment of the town and Duke Janusz Radziwiłł personally, and also by the fact that Matthias Held was the duke's personal physician.

\section{References}

Biographisches Lexikon der Hervorragenden Aerzte aller Zeiten und Völker (1886), Band 3, Wien und Leipzig: Urban \& Schwarzenberg.

CERL (n.d.), 'Held, Matthias ( -1563$)$ ', CERL Thesaurus. Retrieved from http:// thesaurus.cerl.org/record/cnp00878963 [accessed 24 Mar 2015]

Ivanovič, M. (1998), XVII a. Lietuvos lenkiškos knygos. Kontrolinis sąrašas [Polish books in Lithuania in the $17^{\text {th }}$ century], Vilnius: LNB BKC.

Jarczykowa, M. (1995), Ksiaźka i literatura w kręgu Radziwittow birżańskich w pierwszej połowie XVII wieku [Books and literature of Biržai Radziwiłł family in the first half of the $17^{\text {th }}$ century], Kartowice: Wydawnictwo Uniwersytetu Śląskiego.

Kasperavičienè, A. (2006), Kédainiu medicinos istorija [History of medicine in Kèdainiai], Kaunas: Lututè.

Lokotko, A. I.; Knyazeva, O. N.; Morozov, E. V. \& Izotova, O. V. (2013), 'The Dnieper River Area of Gomel Region,' in A. I. Lokotko et al. (eds.) Tourist Mosaic of Belarus, Belaruskaya navuka, pp. 244-283. 
Lukšaitė, I. (2001), 'Knygos nobažnystès krikščioniškos (1653) parengimo kultūrinẻ aplinka' [Cultural environment during preparation of the Book of Christian devotion], in Knyga nobažnystès krikšćioniškos (1653): XVII a. Lietuvos kultūros paminklas [Book of Christian devotion: a seventeenth-century cultural monument of Lithuania], Kèdainiai: Kèdainių krašto muziejus, pp. 4-29.

(2006), 'Vilniaus vaivados Jonušo Radvilos - asmeninès bibliotekos sąrašas asmens kultūrinių orientacijų žymuo' [The list of books in the Kèdainiai personal library of Vilnius Palatine Janusz Radziwiłł: an indicator of his cultural orientation], in Lietuvos istorijos instituto Metraštis 2005/2 [Chronicle of the Lithuanian Institute of History 2005/2], Vilnius: Lithuanian Institute of History, pp. 29-52.

Meškauskas, J. (1987), Lietuvos medicinos istorija [History of medicine in Lithuania], Chicago: World Lithuanian Medical Association.

Meyers Großes Konversations-Lexikon (1909), Band 19, Leipzig \& Wien: Bibliographisches Institut.

Narbutienè, D. (2001), LDK lotyniškoji knyga asmeninėse XVI-XVII a. bibliotekose [The GDL Latin books in personal libraries of the $16^{\text {th }}-17^{\text {th }}$ centuries], Knygotyra, vol. 37, pp. 138-152.

— (2004), Lietuvos Didžiosios kunigaikštijos Lotyniškoji knyga [Latin books in the Grand Duchy of Lithuania], Vilnius: The Institute of Lithuanian Literature and Folklore.

Narbutienè, D. \& Narbutas, S. (1998), XVII a. Lietuvos lotyniškų knygu sąrašas [List of Latin books in Lithuania in the $17^{\text {th }}$ century], Vilnius: The Institute of Lithuanian Literature and Folklore.

Plečkaitis, R. (1975), Feodalizmo laikotarpio filosofija Lietuvoje [Philosophy of the feudal period in Lithuania], Vilnius: Mintis.

Šinkūnas, P. (1928), Kédainiu miesto istorija [History of Kèdainiai], Kaunas: Spindulys. Stownik liekarzów Polskich... (1885), [The lexicon of Polish Physicians...], Warszawa: Druk K. Kowalewskiego.

Vaitkevičienè, V. (2007), Kédainiu gimnazijos istorija, 1625-1956 [History of gymnasiums in Kèdainiai, 1625-1956], Kèdainiai: Spaudvita.

Visuotine lietuviu enciklopedija (2011), [Universal Lithuanian Encyclopaedia] Vilnius: Science and Encyclopaedia Publishing Institute, vol. 19, p. 502.

Wisner, H. (2000), Jonušas Radvila (1612-1655): Kédainių šešèlyje [Janusz Radziwiłł (1612-1655): the shadows of Kedainiai], Vilnius: Vaga.

Worldcat (n.d.), 'Matthias Held,' Worldcat.org. Retrieved from http://www.worldcat.org/ identities/viaf-40309008/ [accessed 24 Mar 2015] 